$\exp _{e}, \exp _{10}=$ Exponential value to base " $e$ " or base "10" (=antilogarithm).

Dose $=$ Calculated requirement of acid or base in mmol.

Required ventilation $=$ Ventilation calculated to correct $\mathbf{P C O}_{2}$ $\mathrm{DpH}=$ Difference between $\mathbf{7 \cdot 4}$ and $\mathrm{ApH}$.

$f=$ Frequency.

\section{Addendum}

This program has recently been adapted for use with an Olivetti Programma 602. Copies of the program are available from the author.

\section{References}

Astrup, P. (1956). Scandinavian fournal of Clinical and Laboratory Investigation, $8,33$.

Hardt, J. (1972). Clinical Chemistry, 18, 658

Jalowayski, A., Lauterbach, R., Smith, B. E., and Modell, J. H. (1968) fournal of Laboratory and Clinical Medicine, 71, 328.

Mellemgaard, K., and Astrup, P. (1960). Scandinavian fournal of Clinical and Laboratory Investigation, 12, 187.

Siggaard Anderson, O. (1962). Scandinavian Fournal of Clinical and Laboratory Investigation, 14, 598 .

Siggaard Anderson, O., and Engal, K. (1960). Scandinavian fournal of Clinical and Laboratory Investigation, 12, 177.

Siggaard Andersen, O., Engel, K., Jorgensen, K., and Astrup, P. (1960) Scandinavian fournal of Clinical and Laboratory Investigation, 12, 172 .

Vallbona, C., Pevny, E., and McMath, F. (1971). Computers and Biomedical Research, 4, 623 .

\title{
Specificity of Serum Creatine Kinase Isoenzymes in Diagnosis of Acute Myocardial Infarction
}

\section{A. KONTTINEN, H. SOMER}

British Medical fournal, 1973, 1, 386-389

\section{Summary}

A study of the diagnostic value of serum creatine kinase (CK) isoenzymes showed that MB isoenzyme, which characterizes heart tissue, was a specific and sensitive indicator of acute myocardial infarction. In cases where the clinical picture was complicated by ventricular tachycardia, severe congestive failure, shock, or resuscitation procedures heart, liver, and muscle enzymes were increased. There was also an increase in lactate dehydrogenase isoenzyme values in these cases; indeed, the only enzyme test that correlated well with electrocardiographic and necropsy findings was the MB isoenzyme.

\section{Introduction}

Serum creatine kinase (CK) measurement is established as a sensitive indicator of acute myocardial infarction. Serum CK activity is raised, however, in muslce diseases (Pearce et al., 1964), brain damage (Dubo et al., 1967), alcoholism (Konttinen et al., 1970), and sometimes in pulmonary embolism (Perkoff, 1968) or after electroconversion of heart rhythm (Konttinen et al., 1969). The specificity may be expected to be improved by serum CK isoenzyme determinations, since the $\mathrm{MB}$ isoenzyme of $\mathrm{CK}$ is found almost exclusively in the myocardium (Van der Veen and Willebrands, 1966).

The first approach to evaluate the contribution of the myocardium to the serum CK isoenzymes was made recently in selected patients with proved uncomplicated transmural infarctions (Konttinen, and Somer 1972). The patients were selected in order to avoid the possible extracardiac release of CK isoenzymes into the serum. The present study was undertaken to evaluate the specificity and sensitivity of serum CK isoenzymes, determined with our improved method (Somer and Konttinen, 1972b), in comparison with other enzyme tests on 61 unselected patients admitted to hospital for substernal pain suggestive of myocardial infarction.

First Department of Medicine, University Central Hospital, Helsinki, and Wihuri Research Institute, Helsinki, Finland

A. KONTTINEN, M.D., Assistant Chief Physician and Senior Lecturer in Medicine

H. SOMER, M.D., Research Fellow

\section{Patients and Methods}

The 61 patients were admitted to hospital within 48 hours after an attack suggestive of coronary disease. Bedside examinations were made during the first two hospital days, with special attention to the appearance of atrial and ventricular gallops, paradoxical pulse, and mitral insufficiency, all of which are observable in most cases of acute myocardial infarction (Heikkilä et al., 1971). Besides the conventional 12-lead E.C.G., body temperature, leukocyte count, and sedimentation rate were measured.

Myocardial infarction was regarded as proved by the appearance of $Q R S$ complexes or a $Q$ wave exceeding $0.04 \mathrm{sec}$, and having a depth of at least one-fourth of the corresponding $R$ wave and, in patients with mainly posterior infarcts according to Perloff (1964), where subendocardial extension reached the inferoapical region (leads III and aVF or V5 and V6). At necropsy in one of these patients an acute infarct was found. Because some uncertainty always exists in cases of subendocardial infarction, indicated by coronary-type S-T and/or $T$ changes, this group was considered separately. The total series was divided into four groups.

Eighteen patients had an acute coronary attack with no evidence of myocardial infarction on the above-mentioned criteria.

Twenty-seven patients had acute proved myocardial infarction with no complications. Some, however, had slight left heart failure, as evidenced by rales in the lungs, but no pulmonary oedema. The infarcts were anteroseptal in 17 cases, inferior and/or inferoapical in 7, and mainly posterior and extending into the inferoapical region in 3.

Seven patients had acute subendocardial infarction, six anterior and one inferior.

Nine patients had suspected acute myocardial infarction with complications of an emergency character (see table II). Of these, six patients were in shock on admission for ventricular tachycardia or fibrillation, and in three the chest pain was accompanied by severe congestive heart failure. Five patients had E.C.G. evidence of an acute myocardial infarct, which was verified in one at necrosy. Despite the clinical picture four patients did not have E.C.G. evidence of acute infarction, and in one it was excluded at necropsy.

Analyses were made of the following enzymes from unhaemolysed sera taken during the first two hospital days, as reported earlier (Elliot and Wilkinson, 1961; Konttinen et al., 1969): lactate dehydrogenase (LD) and its isoenzymes, $\alpha$-hydroxybutyrate dehydrogenase (HBD), aspartate aminotransferase 
TABLE I-Mean (S.E.) Serum CK and LD Isoenzyme Values in Patients with Myocardial Infarction compared with Other Serum Enzyme Activities. Numbers in Parentheses indicate Upper Limits of Normal $(P<0.01)$

\begin{tabular}{|c|c|c|c|c|c|c|c|c|c|c|c|c|c|c|c|}
\hline Hospital Day & $\begin{array}{l}\text { CK } \\
\text { IU/1. } \\
\text { (35) }\end{array}$ & $\begin{array}{l}\text { MB } \\
\text { IU/1. } \\
(0)\end{array}$ & $\begin{array}{c}\text { MB } \\
\% \\
(0)\end{array}$ & $\begin{array}{c}\text { MM } \\
\% \\
(100)\end{array}$ & $\begin{array}{c}\text { BB } \\
\% \\
(0)\end{array}$ & $\begin{array}{l}\text { LD } \\
\text { IU/1. } \\
(204)\end{array}$ & $\begin{array}{l}\mathrm{LD}_{1} \\
\mathrm{IU} / 1 . \\
\text { (101) }\end{array}$ & $\begin{array}{l}\mathrm{LD}_{2} \\
\text { IU/I. } \\
(89)\end{array}$ & $\begin{array}{l}\mathrm{LD}_{3} \\
\mathrm{IU} / 1 . \\
(38)\end{array}$ & $\begin{array}{c}\mathrm{LD}_{4} \\
\text { IU/I. } \\
\text { (5) }\end{array}$ & $\begin{array}{c}\mathrm{LD}_{5} \\
\text { IU/1. } \\
\text { (7) }\end{array}$ & $\underset{\substack{\text { IU } \\
\text { IU/1. } \\
\text { (132) }}}{\text {. }}$ & $\underset{\substack{\text { IU/1. } \\
(18)}}{\text { SGOT }}$ & $\begin{array}{c}\text { SGPT } \\
\text { IU⿴) }\end{array}$ & $\begin{array}{l}\text { OCT } \\
\text { IU/1. } \\
(0 \cdot 40)\end{array}$ \\
\hline \multicolumn{16}{|c|}{ Patients with Acute Proved Myocardial Infarction $(\mathrm{n}=27)$} \\
\hline $1\left\{\begin{array}{l}\text { Mean } \\
\text { S.E. } \\
\text { Mean } \\
\text { S.E. }\end{array}\right.$ & $\begin{array}{r}403 \cdot 7 \\
88 \cdot 7 \\
302 \cdot 8 \\
54 \cdot 6\end{array}$ & $\begin{array}{r}113.3 \\
30.5 \\
65.4 \\
19.5\end{array}$ & $\begin{array}{r}20 \cdot 8 \\
2 \cdot 6 \\
17 \cdot 8 \\
2 \cdot 1\end{array}$ & $\begin{array}{r}79 \cdot 2 \\
2 \cdot 6 \\
82 \cdot 2 \\
2 \cdot 1\end{array}$ & $\begin{array}{l}0 \\
0 \\
0 \\
0\end{array}$ & $\begin{array}{r}503.3 \\
78.0 \\
721.7 \\
83.8\end{array}$ & $\begin{array}{r}256 \cdot 4 \\
42.1 \\
363.3 \\
46.8\end{array}$ & $\begin{array}{r}180 \cdot 6 \\
29 \cdot 2 \\
268 \cdot 4 \\
34 \cdot 6\end{array}$ & $\begin{array}{r}76 \cdot 4 \\
9.9 \\
80 \cdot 2 \\
9 \cdot 3\end{array}$ & $\begin{array}{l}3.4 \\
1.0 \\
3.5 \\
1.2\end{array}$ & $\begin{array}{l}3.8 \\
1.0 \\
5.5 \\
1.6\end{array}$ & $\begin{array}{r}418 \cdot 7 \\
66.7 \\
573.7 \\
68.9\end{array}$ & $\begin{array}{r}87.5 \\
18.5 \\
101 \cdot 7 \\
15.5\end{array}$ & $\begin{array}{r}22 \cdot 0 \\
3 \cdot 2 \\
27 \cdot 2 \\
3 \cdot 1\end{array}$ & $\begin{array}{l}0.53 \\
0.10 \\
0.36 \\
0.06\end{array}$ \\
\hline \multicolumn{16}{|c|}{ Patients with Acute Subendocardial Infarction $(\mathrm{n}=7)$} \\
\hline $1\left\{\begin{array}{l}\text { Mean } \\
\text { S.E. } \\
2\left\{\begin{array}{l}\text { Mean } \\
\text { S.E. }\end{array}\right.\end{array}\right.$ & $\begin{array}{r}134 \cdot 7 \\
28.3 \\
99 \cdot 0 \\
14.5\end{array}$ & $\begin{array}{r}23 \cdot 9 \\
7 \cdot 8 \\
9 \cdot 7 \\
4 \cdot 7\end{array}$ & $\begin{array}{r}14 \cdot 3 \\
4 \cdot 0 \\
7 \cdot 3 \\
3 \cdot 1\end{array}$ & $\begin{array}{r}85.7 \\
4.0 \\
92 \cdot 7 \\
3.1\end{array}$ & $\begin{array}{l}0 \\
0 \\
0 \\
0\end{array}$ & $\begin{array}{r}292.9 \\
50.5 \\
315.8 \\
67.0\end{array}$ & $\begin{array}{r}156 \cdot 7 \\
38.6 \\
153.5 \\
35.6\end{array}$ & $\begin{array}{r}83 \cdot 0 \\
9 \cdot 2 \\
106 \cdot 2 \\
24 \cdot 3\end{array}$ & $\begin{array}{r}36 \cdot 7 \\
4 \cdot 2 \\
44 \cdot 2 \\
11 \cdot 1\end{array}$ & $\begin{array}{l}5 \cdot 0 \\
1.9 \\
5 \cdot 8 \\
2.8\end{array}$ & $\begin{array}{r}8 \cdot 4 \\
2 \cdot 5 \\
16 \cdot 2 \\
5 \cdot 0\end{array}$ & $\begin{array}{r}212 \cdot 1 \\
43 \cdot 1 \\
231 \cdot 2 \\
58 \cdot 2\end{array}$ & $\begin{array}{r}44.0 \\
13 \cdot 0 \\
32 \cdot 7 \\
5.3\end{array}$ & $\begin{array}{r}17 \cdot 3 \\
1 \cdot 4 \\
18 \cdot 7 \\
4 \cdot 0\end{array}$ & $\begin{array}{l}0.48 \\
0.09 \\
0.80 \\
0.20\end{array}$ \\
\hline
\end{tabular}

(SGOT), alanine aminotransferase (SGPT), and ornithine carbamoyltransferase (OCT). CK was determined with the activated ultraviolet-test sets of Boehringer (Mannheim) and $\mathrm{CK}$ isoenzymes were determined fluorometrically (Somer and Konttinen, 1972b).*

The upper normal limits of the enzymes, shown in table I, were calculated from the serum samples of 30 healthy subjects with a confidence limit of $1 \%(P<0.01)$. The upper normal limit of $M B$ isoenzyme was estimated to be $5 \mathrm{IU} / \mathrm{l}$. This isoenzyme was not found in normal sera. On inspection under ultraviolet light the activity of $5 \mathrm{IU} / 1$. is clearly visible (fig. 1), but scanning is not accurate below 3-5 IU/1.

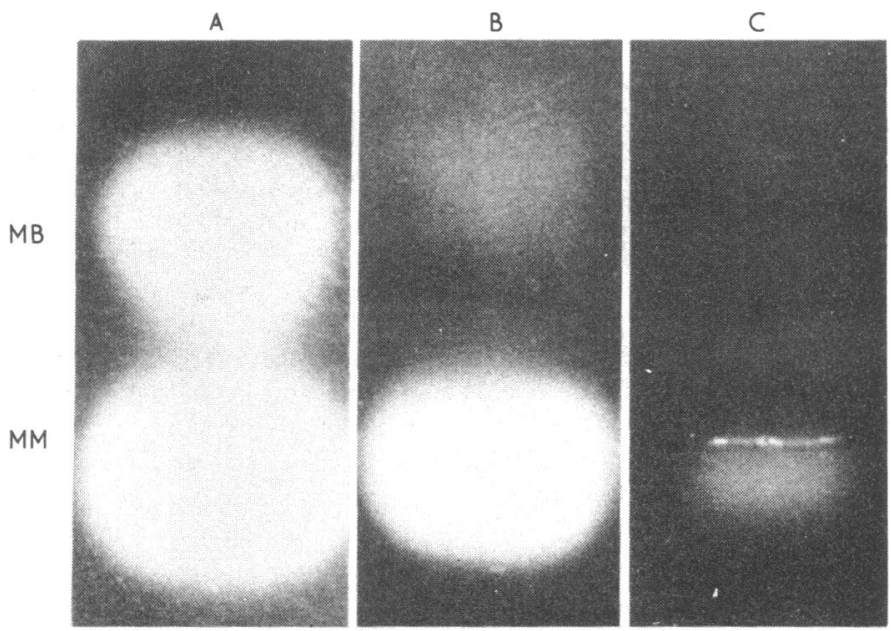

FIG. 1-CK isoenzyme electrophoreses photographed under ultraviolet light. $A=$ Patient with transmural myocardial infarction, total CK activity 330 IU $/ 1$. and $M B$ isoenzyme $112 \mathrm{IU} / 1$. $\mathrm{B}=$ Subendocardial infarction, total CK $90 \mathrm{IU} / 1$. and $\mathrm{MB} 15 \mathrm{IU} / \mathrm{l}$. C = Normal serum with total CK activity 5 IU/l., having no MB isoenzyme. Upper normal limit ot total CK 35 IU/I.

\section{Results}

The mean enzyme activities and their standard errors are given in table $I$ for patients with uncomplicated infarction. Serum MB isoenzyme, together with the total CK activity, reached a peak value on the first hospital day. The highest MB activity recorded was $545 \mathrm{IU} / 1$. and the highest proportion of $\mathrm{MB} 40 \%$. BB isoenzyme, which characterizes lung and brain tissues, was not present in any of the sera. Patients with angina pectoris had only muscle-type CK isoenzyme (MM) in their sera, which accords with findings in healthy persons.

For comparison of the sensitivity of the "heart" enzymes the individual peak values in patients with uncomplicated infarction are presented in relative values in fig. 2. Serum MB isoenzyme was observed to be the most sensitive indicator. One patient with proved infarct, however, did not have MB-isoenzyme in the serum on either test day, although the total CK activity was * In the paper by Somer and Konttinen (1972b) an omission was made in the incubation mixture given in the method. In addition to the other chemicals dissolved in the $5 \mathrm{ml}$ of glycylglycine buffer, dissolve $40 \mathrm{mg}$ glucose.

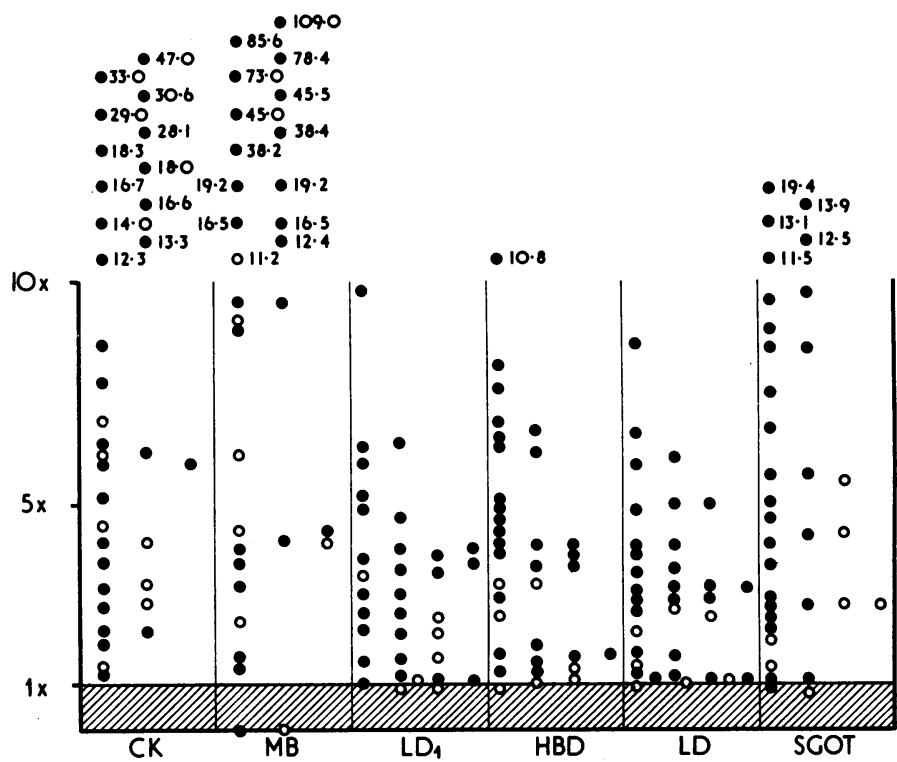

FIG. 2-Peak values of serum "heart enzymes" during first two hospital days. Activities are presented in relative values where the number 1 signifies the upper normal limit $(P<0.01)$ and the other numbers signify how many times this is exceeded. $=$ Patients with proved myocardial infarction. $O=$ Patients with acute subendocardial infarction.

modestly raised (99 and $49 \mathrm{IU} / 1$.). In this patient the $\mathrm{LD}_{1}$, total LD, and HBD values were normal on the first day but slightly raised on the second $(119,235$, and $225 \mathrm{IU} / 1$.) respectively, and the appearance of a $Q$ wave in leads $V 1$ and $V 2$ with negative $\mathrm{T}$-wave changes in leads V1 to V6 indicated septal infarction with anterior subendocardial extension.

Of the patients with subendocardial infarction (fig. 2) one did not have $M B$ isoenzyme in the serum and the $L_{1}, \mathrm{HBD}$, and total LD did not deviate from normal on either day. The slight increases in SGOT (21 and $25 \mathrm{IU} / 1$.) may have been derived from the liver, as judged by the more pronounced abnormalities in OCT, $\mathrm{LD}_{5}$, and SGPT on both days. Total CK was slightly raised on the second day (33 and $49 \mathrm{IU} / 1$.). In the E.C.G. coronary-type negative $T$ waves appeared in leads $V 2$ to V6 on the first hospital day. In a further patient, on the other hand, the total $C K$ was 132 and $148 \mathrm{IU} / 1$. and the MB isoenzyme level 25 and $31 \mathrm{IU} / 1$. However, $\mathrm{LD}_{1}$, total LD, and SGOT activities remained normal on both days, and HBD was found to be only minimally abnormal (135 IU/1.). In the E.C.G. coronary-type S-T changes with negative $T$ waves in leads V2 to V6 appeared on the first day.

The "heart and liver" enzyme activities in the sera of the nine patients with complications are shown in table II. In cases 1 to 4, where infarct could not be confirmed, the enzyme activities were greatly above normal with the exception of $\mathrm{LD}_{1}$, which although raised in all four cases was only slightly above normal in two. MB isoenzyme was absent from the sera of all of these four patients. In the remaining five patients in whom infarction was proved MB isoenzyme was found in the sera, and the levels 
TABLE II-Serum "Heart and Liver" Enzyme Activities (in IU/l.) in Nine Patients with Complications. In the First Four Myocardial Infarction Could Not be Verified, while in the Last Five the Infarction was Confirmed. Upper Normal Limits as in Table I.

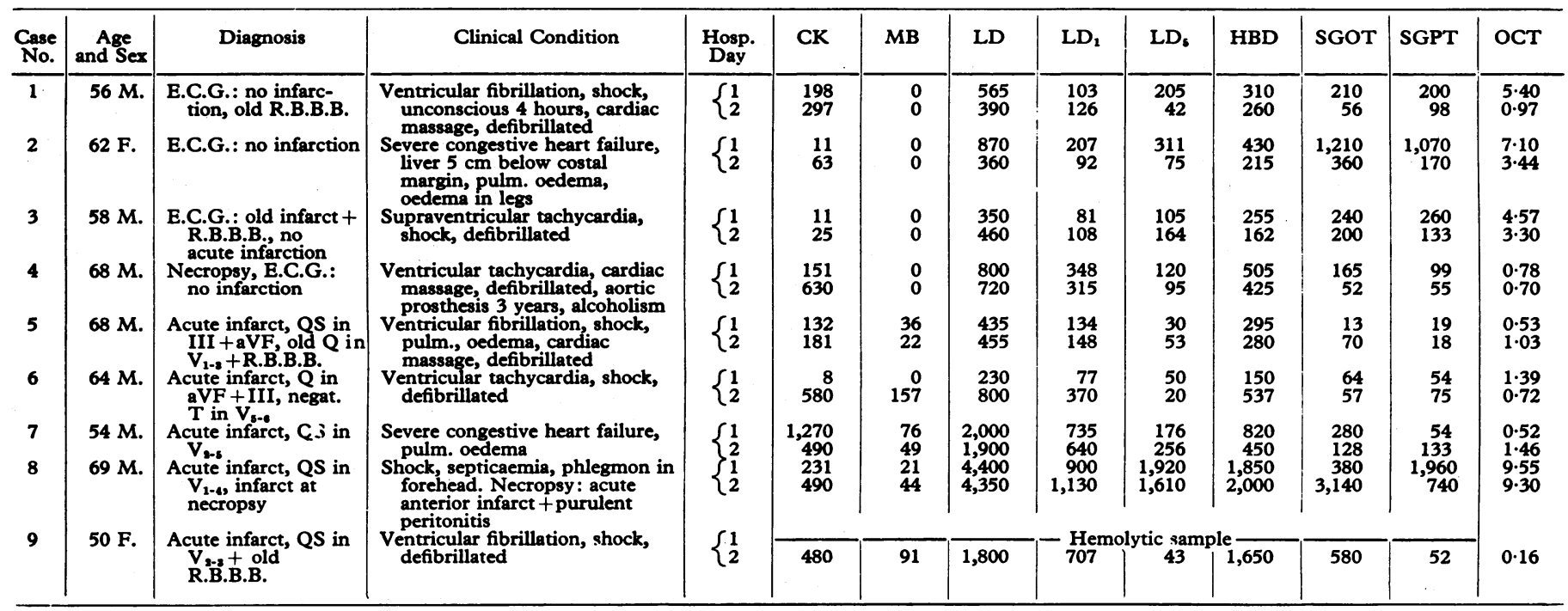

R.B.B.B. = Right bundle-branch block.

of all the other enzymes were so high that extracardiac release was clear.

After $M B$ isoenzyme serum $\mathrm{LD}_{1}$ gave the nearest correct information in these nine patients. Although it indicated myocardial infarction in the four patients in whom it could not be confirmed, the levels were only slightly above normal in two cases. We calculated $\mathrm{LD}_{1}$ activity in terms of $\mathrm{IU} / \mathrm{l}$. because by so doing an infarct is more accurately revealed (Auvinen, 1972). This was also found in the present series, where the proportion of $L D_{1}$ failed to show infarction in any of the five patients in whom it was confirmed, because the massive increases of the other $\mathrm{LD}$ isoenzymes depressed the proportionate share of $\mathrm{LD}_{1}$ to a subnormal level despite the huge increases expressed in IU/1.

\section{Discussion}

The total serum CK test has been advocated as an indicator of myocardial infarction (Smith, 1967), principally because this enzyme is lacking in the liver and erythrocytes (Colombo et al., 1962), both of them common sources of error in infarct diagnosis by means of serum enzyme tests. However, serum total CK activity also increases in some other diseases (Pearce et al., 1964; Dubo et al., 1967; Perkoff, 1968; Konttinen et al., 1969) The MB isoenzyme of $\mathrm{CK}$ appears to constitute a quite specific indicator of heart damage, since it has been found outside the myocardium in skeletal muscle only with very slight activity (Somer and Konttinen, 1972a; Takahashi et al., 1972). Other organs that have high CK activities are the brain, though this contains BB isoenzyme, and skeletal muscles, which have MM isoenzyme. Lung tissue has only low CK activity, consisting of BB isoenzyme (Van der Veen and Willebrands, 1966; Perkoff, 1968).

The $\mathrm{LD}_{1}$ isoenzyme, so far considered to be the most specific infarct detector (Auvinen, 1972), occurs outside the myocardium in high activities in erythrocytes and kidney and in moderate activities in most organs (Wróblewski and Gregory, 1961). Thus the organ distribution of the $\mathrm{MB}$ isoenzyme exceeds remarkably in myocardial specificity all the known enzymes and isoenzymes.

The present results are the first to confirm the specificity of the MB isoenzyme. This is best evaluated in patients with complications (table II). Serum MB isoenzyme was the only one to show correctly the underlying heart disease when E.C.G. and necropsy were considered to indicate or exclude an infarct.

All of nine patients with complications had such high levels of serum enzymes that extracardiac release was obvious from the liver, as judged from the massive increases of the liverspecific enzyme OCT (Reichard, 1960), but the high levels of MM isoenzyme alone in three patients point to skeletal muscle as a contributing organ. Serum $\mathrm{LD}_{5}$, SGOT, and SGPT may be derived either from the liver or from skeletal muscle or from both.

The interpretation of serum CK isoenzyme analyses can be done either by visual inspection of the bands under an ultraviolet lamp or by fluorometric quantitation. Because we were unable to find $\mathrm{MB}$ isoenzyme in sera from healthy subjects or from patients with angina pectoris this method seems to offer a "plus or minus" test for the detection of myocardial damage. When used as a plus or minus test the scanning of the electrophoretic plates is not necessary, although this was done in the present study.

Although skeletal muscles contain only small amounts of $\mathrm{MB}$ isoenzyme it might be thought that muscular diseases would cause its leakage into the serum. Our experience is so far limited to some few cases in which we have not found $M B$ in the serum. Electroconversion of heart rhythm has been observed to produce abnormal readings in serum total CK activity, presumably from skeletal muscles (Konttinen et al., 1969). Among 40 patients electroconversion caused a rise of serum CK activity in 15; this was wholly of muscle-type isoenzyme (MM). Similarly, out of 16 patients with acute pulmonary embolism five had somewhat raised serum total CK activity, and it consisted of muscle-type isoenzyme.

Besides myocardial infarction the only disease so far found to be associated with $\mathrm{MB}$ isoenzyme in the serum is muscular dystrophy of Duchenne (15 cases analysed). This rare hereditary disease is known to convert also serum LD isoenzyme from muscle type into heart type (Wieme and Herpol, 1962). This disease, however, rarely comes into consideration in differential diagnosis from myocardial infarct, since it usually leads to death in childhood.

This work was aided by the grants from the Sigrid Jusélius Foundation, Finnish Heart Association, Finnish Medical Council, and the Paulo Foundation. Requests for reprints should be addressed to Dr. A. Konttinen.

\section{References}

Auvinen, S. (1972). Acta Medica Scandinavica, Suppl. No. 539 Colombo, J. P., Richterich, R., and Rossi, E. (1962). Klinische Wochenschrift, $40,37$. 
Dubo, H., Park, D. C., Pennington, R. J. T., Kalbag, R. M., and Walton, J. N. (1967). Lancet, 2, 743.

Elliot, B. A., and Wilkinson, J. H. (1961). Lancet, 1, 698.

Heikkilä, J., Luomanmäki, K., and Pyörälä, K. (1971). Acta Medica Scandinavica, 190, 89.

Konttinen, A., Hupli, V., Louhija, A., and Härtel, G. (1969). New England Fournal of Medicine, 281, 231.

Konttinen, A., Härtel, G., and Louhija, A. (1970). Acta Medica Scandinavica, $188,257$.

Konttinen, A., and Somer, H. (1972). American fournal of Cardiology, 29, 817.

Pearce, J. M. S., Pennington, R. J., and Waltor, J. N. (1964). Fournal of Neurology, Neurosurgery and Psychiatry, 27, 96.
Perkoff, G. T. (1968). Archives of Internal Medicine, 122, 326.

Perloff, J. (1964). Circulation, 30, 706.

Reichard, H. (1960). Fournal of Laboratory and Clinical Medicine, 56, 218

Smith, A. F. (1967). Lancet, 2, 178.

Somer, H., and Konttinen, A.' (1972a). Clinica Chimica Acta, 36, 531.

Somer, H., and Konttinen, A. (1972a). Clinica Chimica Acta, 36, 531.

Takahashi, K., Ushikubo, S., Oimomi, M., and Shinko, T. (1972). Clinica Chimica Acta, 38, 285.

Van der Veen, K. J., and Willebrands, A. F. (1966). Clinica Chimica Acta, 13, 312 .

Wieme, R. J., and Herpol, J. E. (1962). Nature, 194, 288.

Wróblewski, F., and Gregory, K. F. (1961). Annals of the New York Academy of Sciences, 94, 912 .

\title{
Primary Acquired Sideroblastic Anaemia: Response to Treatment with Pyridoxal-5-Phosphate
}

\author{
D. Y. MASON, PAULINE M. EMERSON
}

British Medical fournal, 1973, 1, 389-390

\section{Summary}

A 72-year-old woman with primary sideroblastic anaemia showed no response to treatment with pyridoxine. When she was given pyridoxal-5-phosphate there was a prompt reticulocyte response and sustained symptomatic improvement with satisfactory control of the anaemia.

\section{Introduction}

Primary acquired sideroblastic anaemia is a well-defined form of anaemia characterized by a heavy perinuclear infiltrate of iron-containing granules in the developing marrow normoblasts. These "ring" sideroblasts are thought to represent an unidentified defect in haem synthesis (Bessis and Jensen, 1965; Bousser et al., 1967), which for some reason usually manifests itself only in the later decades of life (Macgibbon and Mollin, 1965). In contrast to the secondary type of sideroblastic anaemia no associated diseases or drug ingestion can be identified.

Pyridoxine is a necessary coenzyme for haem synthesis (Kikuchi et al., 1958; Levere and Granick, 1965), and the possibility that a defect in its metabolism is responsible for sideroblastic erythropoiesis finds support in the appearance of atypical sideroblasts in pyridoxine-deficient animals (Harriss et al., 1965) and in patients receiving pyridoxine antagonists such as cycloserine or isoniazid (Verwilghen et al., 1965). Furthermore, treatment with oral pyridoxine may lead to haematological improvement in cases of sideroblastic anaemia. However, response to pyridoxine is almost always suboptimal and occurs in only $40-50 \%$ of patients (Macgibbon and Mollin, 1965). In addition very large doses of the drug, often 100 times the normal nutritional requirement, may be necessary.

For these reasons it has been suggested that a block in the conversion of pyridoxine to its main active form, pyridoxal5-phosphate, is the underlying cause of sideroblastic anaemia (Hines and Grasso, 1970). This conversion, which can occur within the red cell (Anderson et al., 1971), has been shown to be defective both in alcohol-induced and primary sideroblastic anaemia (Hines and Cowan, 1970; Hines and Love, 1969).

Department of Haematology, Radcliffe Infirmary, Oxford D. Y. MASON, B.M., B.CH., Lecturer in Haematology

PAULINE M. EMERSON, M.D., M.R.C.PATH., Consultant Haematologist
A direct corollary of this hypothesis is that pyridoxal5-phosphate should prove therapeutically much more effective than pyridoxine in sideroblastic anaemia. The present report is of a case of primary acquired sideroblastic anaemia which was unresponsive to prolonged treatment with pyridoxine but which responded dramatically to pyridoxal-5-phosphate.

\section{Clinical History}

The patient was admitted to the Radcliffe Infirmary in July 1968, aged 72 , with a nine-month history of dyspnoea, ankle oedema, and lassitude. Apart from rheumatic fever as a child she had enjoyed good health, having been a regular blood donor until 1960. On examination she was pale and in congestive cardiac failure with evidence of mitral and aortic valve incompetence. The haemoglobin was $4.8 \mathrm{~g} / 100 \mathrm{ml}$ and the peripheral blood film showed a double population of hypochromic and normochronic erythrocytes, together with numerous poikilocytes and occasional nucleated red cells. Bone marrow aspiration showed erythroid hyperplasia with a disproportionate increase in early red cell precursors. Most of the later forms were shown to be ring sideroblasts on Perl's staining. These cells were negative on P.A.S. staining and marrow chromosome preparations were normal.

Results of biochemical tests were normal except for a serum bilirubin of $1.0 \mathrm{mg} / 100 \mathrm{ml}$ and a plasma lactic dehydrogenase of 300 $\mathrm{mU} / \mathrm{ml}$. The plasma iron was $150 \mu \mathrm{g} / 100 \mathrm{ml}$, with a saturation of $48 \%$. Ferrokinetic studies with ${ }^{50} \mathrm{Fe}$ showed an increased plasma clearance $\left(\mathrm{t} \frac{1}{2} 12 \mathrm{~min}\right.$.) and a reduced red cell utilization ( $22 \%$ on day 14$)$. Careful investigation failed to produce evidence of any other disease.

After transfusion and conventional therapy for congestive failure treatment was started with oral folate $(5 \mathrm{mg}$ three times a day) to which was later added pyridoxine ( $100 \mathrm{mg}$ twice daily) and ascorbic acid (200 mg twice daily). Each drug was given continuously for several months without any evidence of haematological response (see chart). Further transfusions were given in September and December 1968 but by February 1969 the haemoglobin had fallen to 7.0 $\mathrm{g} / 100 \mathrm{ml}$. At this stage, because of a transient reticulocytosis which had been noted during her first admission following a tryptophan loading test (see chart), she began taking oral tryptophan at an initial dose of $2 \mathrm{~g}$ daily, later increased to $\mathbf{4 g}$ daily, in addition to the other haematinics. Although this new treatment appeared to cause a reticulocytosis and an increase in haemoglobin, the improvement was transient. She developed diarrhoea, and in May, after a total consumption of $280 \mathrm{~g}$ of tryptophan, all treatment for anaemia was stopped.

After a further transfusion she maintained a haemoglobin level of $7.5 \mathrm{~g} / 100 \mathrm{ml}$ until November 1969 . She then required increasingly frequent blood transfusions because of recurrent episodes of cardiac failure. Although desferrioxamine treatment had been initiated in November 1968, and was given at the time of each transfusion, a bone marrow specimen in March 1971 showed an increase in storage iron, and a serum iron of $215 \mu \mathrm{g} / 100 \mathrm{ml}$ with $75 \%$ saturation was recorded. By this time she had received a total of 62 units of blood since the diagnosis. In addition the transfusions had been complicated by the 